\title{
PERAN LEMBAGA PERLINDUNGAN KONSUMEN TERHADAP KONSUMEN DAN PELAKU USAHA
}

\author{
Dr. KADI SUKARNA, SH.M.H. ${ }^{1}$
}

\begin{abstract}
ABSTRAK
Penulisan ini dimaksudkan untuk mengetahui tentang perlindungan konsumen dan azas-azas yang berlaku di dalam Undang-Undang Perlindungan Konsumen sesuai Pasal 2 UU No 8 Tahun 1999. Konsumen adalah setiap orang pemakai barang, dan atau jasa yang tersedia dalam masyarakat baik bagi kepentingan diri sendiri, keluarga, orang lain, maupun makluk hidup lain dan tidak untu diperdagangkan. Perlindungan konsumen adalah segala upaya yang menjamin segala kepastian hukum untuk memberi perlindungan kepada Konsumen.Disamping itu membahas tentang hak dan kewajiban konsumen dan pelaku usaha. Sebagaimana rumusan Pasal 4 jo 5 Undang-undang Perlindungan Konsumen. Penegakan hukum Perlindungan Konsumen harus melibatkan banyak pihak terutama pemerintah dan Lembaga Perlindungan Konsumen dan lembaga pengawas lain, serta harus terkoordinasi dengan instansi-instansi terkait supaya terjadi keharmonisan dan tidak tumpang tindih kebijakan atau keputusan. Hal ini diharapkan dapat mendorong pertumbuhan ekonomi dengan baik tanpa harus merugikan konsumen atau pengguna barang/atau jasa. Karena keberadaan Undang-Undang Perlindungan Konsumen ini sudah cukup representatif untuk melindungi konsumen asalkan Undang-undang telah dipahami oleh pelaku usaha dan konsumen.
\end{abstract}

Kata Kunci: Perlindungan, Konsumen dan Pelaku Usaha.

\section{ABSTRACT}

This writing is intended to find out more about consumer protection and the principles that apply in the Consumer Protection Act in accordance with Article 2 of Law No. 8 of 1999. The customer is everybody user of goods and or services available in the community for the benefit of themselves, family, others, as well as other living beings and not untu traded. Consumer protection is all the effort that ensures all legal certainty to provide protection to Konsumen.Disamping it discusses the rights and obligations of consumers and businesses. As the formulation of Article 4 jo 5 Consumer Protection Act. Consumer Protection Law enforcement must involve many parties, especially the government and the Consumer Protection Agency and other supervisory agencies, and must be coordinated with the appropriate agencies to happen harmony and not overlapping policies or decisions.This is expected to stimulate economic growth by fine without harming consumers or users of goods / services. Due to the existence of the Consumer Protection Act is already sufficiently representative to protect consumers as long as the legislation has been understood by businesses and consumers.

Keywords: Protection, Consumer and business communities.

${ }^{1}$ Dosen Pascasarjana Magister Ilmu Hukum Universitas Semarang dan Ketua Lembaga Perlindungan konsumen Swadaya Masyarakat Kab.Karanganyar 


\section{A. PENDAHULUAN}

\section{Latar Belakang}

Konsumen adalah setiap orang pemakai barang, dan atau jasa yang tersedia dalam masyarakat baik bagi kepentingan diri sendiri, keluarga, orang lain, maupun makluk hidup lain dan tidak untu diperdagangkan. ${ }^{2}$ Perlindungan

konsumen adalah segala upaya yang menjamin segala kepastian hukum untuk memberi perlindungan kepada Konsumen. ${ }^{3}$ Tetapi apakah sesuai kenyataan saat ini konsumen benarbenar dapat terlindungi dan lebih mengecewakan yang terjadi konsumen sering dianak-tirikan oleh para produsen. Beberapa contoh kasus tentang makanan kemasan kadaluarsa berbentuk parcel, dan kini banyak beredar serta produk-produk lain yang kadaluarsa, tentu sangat berbahaya apabila dikonsumsi sebab jamur dan bakteri yang berada dalam makanan tersebut bisa menyebabkan keracunan.

Pengolahan daging sisa atau bekas dari hotel dan restoran yang diolah kembali, berita ini menggemparkan publik yang dikenal dengan sebutan daging limbah atau daging sampah. Sebutan namanya saja kita akan merasa jijik dan seakan-akan tidak percaya pada hal tersebut, namun

${ }^{2}$ Lihat Pasal 1 Ayat (2) UU No. 8 Tahun 1999 Tentang Perlindungan Konsumen.

${ }^{3}$ Ibid Ayat (2) ini benar-benar terjadi dan faktanya pelaku ditangkap dikawasan cengkareng, Jakarta Barat. Pengakuan pelaku benar-benar melakukan dan menjelaskan pula tahapan-tahapan yang dilakukannya dalam mengolah daging sampah tersebut. Antara lain; Limbah daging dibersihkan lalu dicuci dengan cairan formalin, selanjutnya diberi pewarna tekstil dan daging digoreng kembali sebelum dijual dalam berbagai bentuk seperti sup, daging empal dan bakso sapi. Lebih mengejutkan lagi bahwa profesi ini sudah ia pratikkan selama 5 (lima) tahun lebih.

Pernah kita mendengar tentang produk susu dari China yang mengandung melamin dan ditemukan di Indonesia. Melamin adalah zat yang biasa digunakan dalam pembuatan perabotan rumah tangga atau plastic. Namun dalam kasus ini melamin dicampurkan dicampurkan dengan susu dampak yang ditimbulkan adalah bayi yang mengalami penyakit tidak lazim seperti, gagal ginjal, bahkan tidak sedikit dari mereka yang meninggal dunia. Pelanggaranpelanggaran hukum yang dilakukan produsen dan atau pelaku usaha ini yang merugikan para konsumen dalam tingkatan yang dianggap sangat membahayakan kesehatan dan jiwa konsumen. 
Ketiga contoh kasus di atas, dapat memberikan gambaran bahwa konsumenlah menjadi pihak yang sangat dirugikan. Disamping itu sering kali konsumen harus membayar mahal untuk biaya berobat kerumah sakit karena resiko-resiko yang diderita adalah sangat membahayakan kesehatan dan jiwa konsumen. Terjadinya dampak seperti ini mungkin disebabkan kurangnya pengawasan dari Pemerintah dan badan-badan hukum seperti Dinas kesehatan, satuan Polisi Pamong Praja, serta dinas Perdagangan dan Perindustrian setempat.

\section{Perumusan Masalah}

Berdasarkan latar belakang tersebut di atas maka rumusan masalah sebagai berikut:

1. Apakah azas-azas perlindungan konsumen?

2. Apakah Hak dan kewajiban konsumen dan Peran lembaga perlindungan konsumen

\section{B. PEMBAHASAN}

\section{Azas Perlindungan Konsumen}

Undang-Undang Dasar 1945, merupakan sumber dari segala sumber hukum di Indonesia, dan dalam hal ini telah mengamanatkan pembangunan nasional bertujuan untuk mewujudkan masyarakat adil dan makmur. Melalui tujuan pembangunan nasional ini maka sistem pembangunan ekonomi harus dikembangkan secara demokratis sserta mampu menumbuhkan kembangkan dunia produksi barang dan jasa yang layak dikonsumsi oleh masyarakat. Undang-Undang No. 8 Tahun 1999 tentang PerlindunganKonsumen (UUPK), diharapkan dapat memberikan rasa aman dan adil bagi masyarakat atau konsumen serta untuk memperoleh perlindungan atas kerugian yang diderita atas transaksi suatu barang dan jasa. Perkembangan perekonomian dan pertumbuhan pembangunan serta pengaruh globalisasi dan kemajuan teknologi akan membawa pengaruh luar biasa kepada setiap aspek kehidupan manusia, khususnya di bidang perindustian dan perdagangan yang menghasilkan barang jasa dalam pemenuhan kebutuhan hidup.

Keadaan inilah sangat membawa keuntungan bagi pelaku usaha terhadap barang-barang yang dihasilkannya dan konsumen akan semakin terbuka sebagai peluang untuk mengkomsumsi barang atau jasa yang dihasilkan dengan harga yang kompetitif. Keuntungan antara pelaku usaha dengan konsumen tersebut ada baiknya tetapi juga akan menimbulkan dampak negatik karena akan mengakibatkan kedudukan pelaku usaha dan konsumen menjadi tidak 
seimbang, pelaku usaha berposisi sebagai pensuplai dan konsumen berada pada posisi yang lemah. Dengan demikian Konsumen sebagai objek bisnis untuk meraup keuntungan yang sebesar-besarnya, pelaku usaha melalui kiat-kiat promosi dan tata cara penjualan yang merugikan konsumen. Maka UndangUndang Perlindungan Konsumen ini lahir sudah cukup representatif apabila telah dipahami oleh semua pihak, karena di dalamnya juga memuat jaminan adanya kepastian hukum bagi konsumen, meningkatkan kualitas barang dan/atau jasa yang menjamin kelangsungan usaha produksi barang dan/atau jasa, kesehatan, kenyamanan, keamanan dan keselamatan konsumen, meningkatkan kesadaran, kemampuan dan kemandirian konsumen untuk melindungi diri, mengangkat harkat dan martabat konsumen dengan cara menghindarkannya dari ekses negatif pemakaian barang dan/atau jasa, meningkatkan pemberdayaan konsumen dalam memilih,menentukan dan menuntut hak-haknya sebagai konsumen. Kemudian di dalam rumusannya pun telah mengatur pula tentang pelarangan bagi pelaku usaha yang tidak mengikuti ketentuan berproduksi secara halal, sebagaimana pernyataan "halal" yang dicantumkan dalam label. Seiring semakin terbukanya pasar bebas sebagai akibat dari proses mekanisme pasar yang berkembang. Ekses yang seringkali timbul adalah transaksi ekonomi yang terjadi sering terdapat permasalahan-permasalahan atau sengketa dan ketidakpuasan konsumen atas produk yang di konsumsinya tidak memenuhi kualitas rasa aman dan bahkan ada yang berbahaya.

Pemerintah melalui lembagalembaganya meningkatkan perlindungan dan jaminan produk, kepastian mutu, jumlah, dan keamanan barang dan jasa yang diperolehnya di pasar, hal ini demi peningkatan kesejahteraan masyarakat. Tentu masih segar di ingatan, ditariknya produk pengusir nyamuk HIT karena dikhawatirkan mengandung bahan yang berbahaya bagi keamanan dan keselamatan konsumen.

Terakhir tetang kasus jamu berbahaya, kosmetik, makananminuman mengandung susu produk RRC yang berbahaya, makanan yang bercampur formalin. beras mengandung bahan pengawet berbahaya dan lain-lain. Pertanyaannya kenapa lembagalembaga pemerintah seakan-akan tidak berfungsi? Padahal secara nyata Pasal 2 UU No 8 Tahun 1999 merumuskan 
bahwa azas Perlindungan Konsumen adalah:

1. Asas Manfaat; mengamanatkan bahwa segala upaya dalam penyelenggaraan perlindungan konsumen harus memberikan manfaat sebesar-besarnya bagi kepentingan konsumen dan pelaku usaha secara keseluruhan,

2. Asas Keadilan; partisipasi seluruh rakyat dapat diwujudkan secara maksimal dan memberikan kesempatan kepada konsumen dan pelaku usaha untuk memperoleh haknya dan melaksanakan kewajibannya secara adil

3. Asas Keseimbangan; memberikan keseimbangan antara kepentingan konsumen, pelakuusaha, dan pemerintah dalam arti materiil ataupun spiritual,

4. Asas Keamanan dan Keselamatan Konsumen; memberikan jaminan atas keamanan dankeselamatan kepada konsumen dalarn penggunaan, pemakaian dan pemanfaatan barangdan/atau jasa yang dikonsumsi atau digunakan;

5. Asas Kepastian Hukum; baik pelaku usaha maupun konsumen mentaati hukum dan memperoleh keadilan dalam penyelenggaraan perlindungan konsumen, serta
Negara menjamin kepastian hukum.

Kesadaran konsumen akan hakhaknya masih rendah, hal ini dipengaruhi beberapa faktor, seperti tingkat pendidikan yang belum memenuhi standar wajib karenanya belum dapat dianggap sebagai konsumen yang cerdas. Undang-Undang Perlindungan Konsumen dimaksudkan untuk menjadi landasan hukum yang kuat bagi pemerintah dan lembaga perlindungan konsumen swadaya masyarakat untuk melakukan upaya pemberdayaan konsumen melalui pendidikan dan pembinaan konsumen. Upaya pemberdayaan ini penting karena tidak gampang menyadarkan pelaku usaha yang telah mendarah daging berpegang teguh dengan prinsipnya," mengeluarkan barang atau modal minimal tetapi mendapatkan keuntungan yang semaksimal mungkin. Konsisi ini sangat potensial merugikan kepentingan konsumen secara langsung maupun tidak langsung.

\section{Hak dan kewajiban konsumen}

Rumusan pasal-pasal UU Nomor 8 Tahun 1999, telah mengatur Hak-hak konsumen dan pelaku usaha, Meskipun realitanya, terkadang konsumen seringkali berada pada posisi yang kurang menguntungkan dan daya tawarnya rendah. Ini karena mereka belum memahami hak-hak 
mereka dan terkadang sudah menganggap itu persoalan biasa saja. Untuk Lembaga pelindungan Konsumen swadaya masyarakat adalah lembaga advokasi kepentingan konsumen yang secara idial mampu memperjuangkan hak-hak konsumen, adapun sesuai dengan Pasal 4 Undangundang Perlindungan Konsumen, Hakhak Konsumen adalah :

a). Hak atas kenyamanan, keamanan dan keselamatan dalam mengkonsumsi barang dan/atau jasa;

b). Hak untuk memilih barang dan/atau jasa serta mendapatkan barang dan/atau jasa tersebut sesuai dengan nilai tukar dan kondisi serta jaminan yang dijanjikan;

c). Hak atas informasi yang benar, jelas dan jujur mengenai kondisi dan jaminan barang dan/atau jasa;

d). Hak untuk didengar pendapat dan keluhannya atas barang dan/atau jasa yang digunakan;

e).Hak untuk mendapatkan advokasi, perlindungan dan upaya penyelesaian sengketa perlindungan konsumen secara patut;

f). Hak untuk mendapat pembinaan dan pendidikan konsumen;

g). Hak untuk diperlakukan atau dilayani secara benar dan jujur serta tidak diskriminatif; h). Hak untuk mendapatkan kompensasi, ganti rugi/penggantian, apabila barang dan/atau jasa yang diterima tidak sesuai dengan perjanjian atau tidak sebagaimana mestinya;

i). Hak-hak yang diatur dalam ketentuan peraturan perundangundangan lainnya.

Maka dengan demikian konsumen pun perlu memiliki dan meningkatkan kesadaran, pengetahuan, kepedulian, kemampuan untuk melindungi dirinya. Sosialisasi Undangundang perlindungan konsumen harus secara gencar dilakukan terutama kepada masyarakat tingkat bawa dan berpendidikan rendah. Karena permasalahan-permasalahan ini tentu akan terjadi akibat dari ketidak pahaman konsumen. Untuk peningkatan kesadaran dan kewaspadaan konsumen, sesuai rumusan Pasal 5 Undang-undang perlindungan konsumen, memiliki kewajiban sebagai berikut::

1. Membaca atau mengikuti petunjuk informasi dan prosedur pemakaian atau pemanfaatan barang dan/atau jasa, demi keamanan dan keselamatan;

2. Beritikad baik dalam melakukan transaksi pembelian barang dan/atau jasa;

3. Membayar sesuai dengan nilai tukar yang disepakati; 
4. Mengikuti upaya penyelesaian hukum sengketa perlindungan konsumen secara patut.

Seperangkat penegakan hukum ada untuk melindungi konsumen dan tidak dimaksudkan untuk mematikan usaha para pelaku usaha, namun timbal balik ini perlindungan konsumen dapat mendorong iklim perusahaan yang tangguh dalam menghadapi persaingan melalui penyediaan barang dan atau jasa yang berkualitas. Pelaksanaan Undangundang Perlindungan konsumen tetap memberikan perhatian khusus kepada pelaku usaha kecil dan menengah. Hal ini dilakukan melalui upaya pembinaan dan penerapan sanksi atas pelanggarannya

Disamping itu sesuai Pasal 6 Undang-undang Perlindungan konsumen, merumuskan hak pelaku usaha adalah:

a. hak untuk menerima pembayaran yang sesuai dengan kesepakatan mengenai kondisi dan nilai tukar barang dan/atau jasa yang diperdagangkan;

b. hak untuk mendapat perlindungan hukum dari tindakan konsumen yang beritikad tidak baik;

c. hak untuk melakukan pembelaan diri sepatutnya di dalam penyelesaian hukum sengketa konsumen;

d. hak untuk rehabilitasi nama baik apabila terbukti secara hukum bahwa kerugian konsumen tidak diakibatkan oleh barang dan/atau jasa yang diperdagangkan;

e. hak-hak yang diatur dalam ketentuan peraturan perundang-undangan lainnya,

Adapun sesuai Pasal 7, merumuskan kewajiban pelaku usaha adalah :

1). beritikad baik dalam melakukan kegiatan usahanya;

2). memberikan informasi yang benar, jelas dan jujur mengenai kondisi dan jaminan barangdan/atau jasa serta memberi penjelasan penggunaan, perbaikan dan pemeliharaan;

3). memperlakukan atau melayani konsumen secara benar dan jujur serta tidak diskriminatif;

4). menjamin mutu barang dan/atau jasa yang diproduksi dan/atau diperdagangkan

berdasarkanketentuan standar mutu barang dan/atau jasa yang berlaku;

5). memberi kesempatan kepada konsumen untuk menguji, dan/atau mencoba barang dan/atau jasa tertentu serta memberi jaminan dan/atau garansi atas barang yang dibuat dan/atau yangdiperdagangkan;

6). memberi kompensasi, ganti rugi dan/atau penggantian atas kerugian akibat penggunaan, pemakaian dan 
pemanfaatan barang dan/atau jasa yang diperdagangkan;

7). memberikompensasi, ganti rugi dan/atau penggantian apabila barang dan/atau jasa yang diterima atau dimanfaatkan tidak sesuai dengan perjanjian.

\section{Peran Lembaga Perlindungan} Konsumen Swadaya Masyarakat

Peran lembaga Perlindungan

Konsumen swadaya masyarakat, yang bergerak di bidang perlindungan konsumen menjadi sangat dibutuhkan dalam masyarakat, perannya yang diakui oleh pemerintah memiliki kesempatan untuk berperan aktif dalam mewujudkan perlindungan konsumen. Lembaga perlindungan konsumen swadaya Masyarakat ini berdiri atas perintah undang-undang dan diakui keberadaannya dan memiliki kegiatan sebagaimana rumusan Pasal 44 Undang-undang Perlindungan Konsumen, antara lain:

a. menyebarkan informasi dalam rangka meningkatkan kesadaran atas hak dan kewajiban dan kehatihatian konsumen dalam mengkomsumsi barang dan/atau jasa;

b. memberikan nasehat kepada konsumen yang memerlukannya;

c. bekerja sama dengan instansi terkait dalam upaya mewujudkan perlindungan konsumen; d. membantu konsumen dalam memperjuangkan haknya, termasuk menerima keluhan atau pengaduan konsumen;

e. melakukan pengawasan bersama pemerintah dan masyarakat terhadap pelaksanaan perlindungan konsumen.

Disisi lain Lembaga Pengawasan dan/atau instansi pemerintah dapat dianggap bertanggungjawab terhadap pengawasan peredaran barang-barang dan jasa yang dikonsumsi masyarakat seperti, BPOM, DINKES dan departemen terkait yang mengeluarkan izin produksi, perdagangan dan peredaran suatu produk. Tidak mudah dikibuli oleh pelaku usaha yang akhirnya merugikan konsumen. Kasuskasus formalin,HIT, susu bercampur melamin sebenarnya yang diketahui oleh badan-badan pemerintah terkait tetapi sengaja di biarkan. Akan tetapi ketika kasus ini menjadi konsumsi publik dan /atau heboh di media cetak maupun elektronik, barulah Pemerintah penindaklajuti, padahal sudak memakan korban yang tidak sedikit dan merugikan konsumen yang tidak dapat dihitung besarnya.

\section{PENUTUP}

\section{Kesimpulan}

Keberadaan UU Perlindungan Konsumen ini sudah cukup representatif 
untuk melindungi konsumen asalkan Undang-undang telah dipahami oleh pelaku usaha dan konsumen. Peran lembaga perlindungan konsumen dan seperangkat penegak hukum lainnya harus secara bersama-sama mendorong tumbuh kembangnya ekonomi tetapi juga tidak merugikan konsumen yang telah mengkonsumsi barang dan/atau jasa tersebut.

\section{Saran}

a). Untuk pemerintah dan lembaga perlindungan konsumen harus menegakkan Undang-Undang secara baik sehingga mampu menjunjung tinggi Azas-azas yang berlaku dalam Undang-undang Perlindungan Konsumen.

b) Memenuhan hak dan Kewajiban konsumen dan Pelaku usaha sebagai asas keseimbangan sebagai salah satu pelaku usaha sehingga tercidan perlindungan hukum. c) Meningkatkan peran serta Lembaga Perlindungan Konsumen swadaya masyarakat sebagai amanah Undangundang Perlindungan Konsumen.

\section{DAFTAR PUSTAKA}

Bandung Sudaryatmo, 1999, Hukum dan Advokasi Konsumen, PT. Citra Aditya Bakti,

Yusuf Sofie, 2000, Perlindungan Konsumen dan InstrumenInstrumen Hukumnya, PT. CitraAditya Bakti,

Undang-Undang Nomor 8 Tahun 1999 Tentang Perlindungan Konsumen Bandung"'http://www.scribd.com/ doc/18545014/makalahperlindungankonsumenhttp://www.pemantaupe radilan.com/delik/16. 
Humani, Vol.6, No.1, Januari 2016 